\title{
Building America's Low-E Storm Window Adoption Program Plan (FY 2014)
}

KA Cort

December 2013

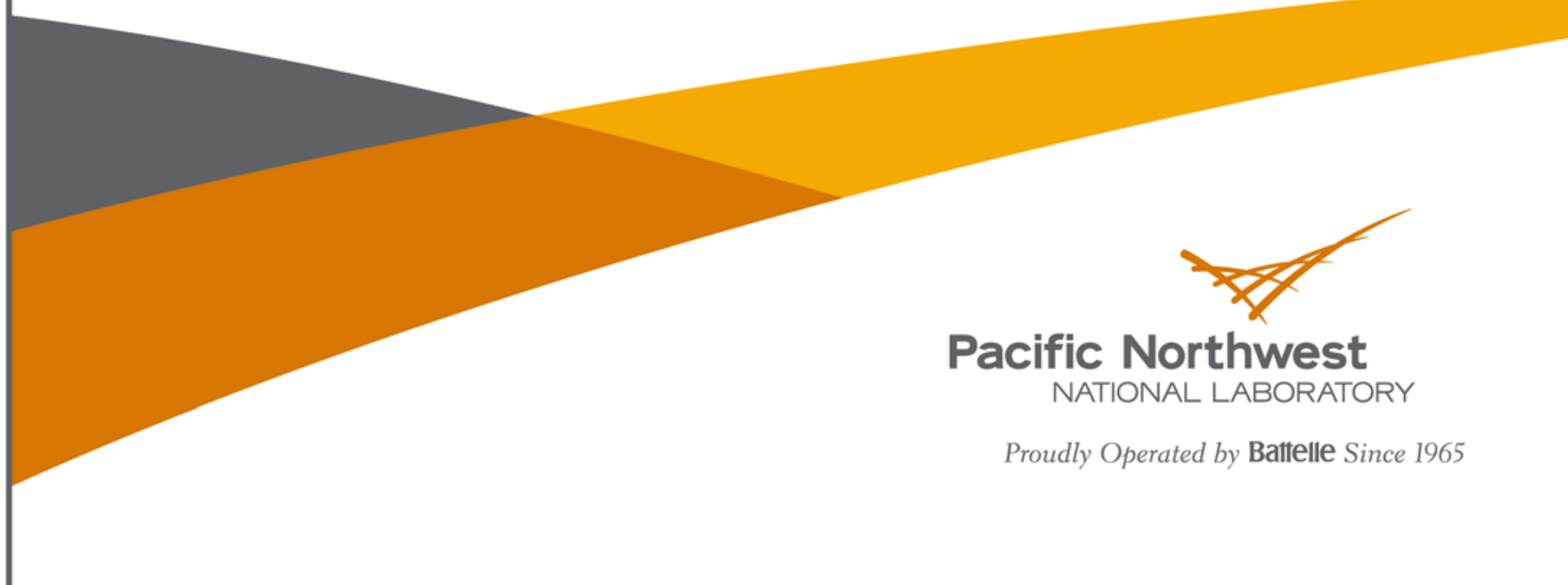




\title{
DISCLAIMER
}

This report was prepared as an account of work sponsored by an agency of the United States Government. Neither the United States Government nor any agency thereof, nor Battelle Memorial Institute, nor any of their employees, makes any warranty, express or implied, or assumes any legal liability or responsibility for the accuracy, completeness, or usefulness of any information, apparatus, product, or process disclosed, or represents that its use would not infringe privately owned rights. Reference herein to any specific commercial product, process, or service by trade name, trademark, manufacturer, or otherwise does not necessarily constitute or imply its endorsement, recommendation, or favoring by the United States Government or any agency thereof, or Battelle Memorial Institute. The views and opinions of authors expressed herein do not necessarily state or reflect those of the United States Government or any agency thereof.

\author{
PACIFIC NORTHWEST NATIONAL LABORATORY \\ operated by \\ BATTELLE \\ for the \\ UNITED STATES DEPARTMENT OF ENERGY \\ under Contract DE-AC05-76RL01830
}

Printed in the United States of America
Available to DOE and DOE contractors from the Office of Scientific and Technical Information,
P.O. Box 62, Oak Ridge, TN 37831-0062;
ph: (865) 576-8401
fax: $(865) 576-5728$
email: reports@adonis.osti.gov
Available to the public from the National Technical Information Service
5301 Shawnee Rd., Alexandria, VA 22312 ph: (800) 553-NTIS (6847)
email: orders@ntis.gov $<$ http://www.ntis.gov/about/form.aspx $>$
Online ordering: http://www.ntis.gov

This document was printed on recycled paper. 


\section{Building America's Low-E Storm Window Adoption Program Plan (FY 2014)}

KA Cort

December 2013

Prepared for

the U.S. Department of Energy

under Contract DE-AC05-76RL01830

Pacific Northwest National Laboratory

Richland, Washington 99352 



\section{Preface}

This report outlines the U.S. Department of Energy (DOE) Building America's planned market transformation activities in support of low-e storm window market adoption during fiscal year (FY) 2014 and also provides the basis for selecting these particular market transformation activities. Although the report may be of general interest to those who work in fields pertaining to building energy-efficiency and/or market adoption of energy-efficiency measures, the primary intent of this report is to document market characteristics, barriers, and activities related to low-e storm windows in order to assist with internal program planning.

The author would like to thank the following staff of Pacific Northwest National Laboratory (PNNL) provided input to this report by participating in a planning workshop on December 12, 2013: Sarah Widder, Jake Knox, Pamela Cole, Graham Parker, and Rosemarie Bartlett. In addition, Doug Dixon, of PNNL and Thomas Culp of BirchPoint Consulting contributed input to the low-e storm window adoption planning process. 




\section{Acronyms and Abbreviations}

\begin{tabular}{ll} 
AEO & Annual Energy Outlook \\
AGC & Asahi Glass Company \\
Building America & Building America (DOE program) \\
BB & Better Building \\
CEE & Consortium for Energy Efficiency \\
CSI & Codes and Standards Innovation \\
DOD & U.S. Department of Defense \\
DOE & U.S. Department of Energy \\
DSIRE & Database of State Incentives for Renewables and Efficiency \\
EISA & Energy Independence and Security Act of 2007 \\
EPA & U.S. Environmental Protection Agency \\
EPAct 2005 & Energy Police Act of 2005 \\
FEMP & Federal Energy Management Program \\
FY & fiscal year \\
GSA & General Services Administration \\
HPwES & Home Performance with Energy Star \\
HUD & U.S. Department of Housing and Urban Development \\
HVAC & heating, ventilation, and air-conditioning \\
IECC & International Energy Conservation Code \\
LBNL & Lawrence Berkeley National Laboratory \\
LIHEAP & Low-Income Home Energy Assistance Program \\
low-e & low emissivity \\
NAHB & National Association of Home Builders \\
NEAT & National Energy Audit Tool \\
NFRC & National Fenestration Rating Council \\
PNNL & Pacific Northwest National Laboratory \\
RECS & Residential Energy Consumption Survey \\
SIR & savings-to-investment ratio \\
WAP & \\
& Weatherization Assistance Program \\
\hline
\end{tabular}





\section{Contents}

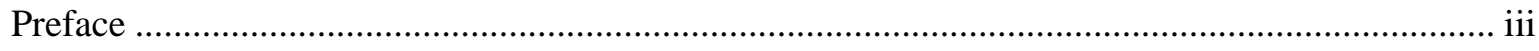

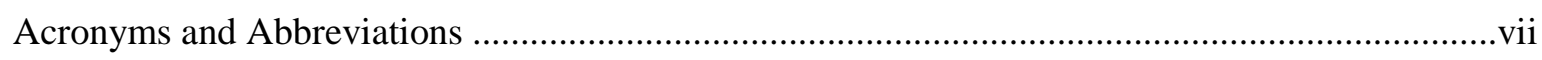

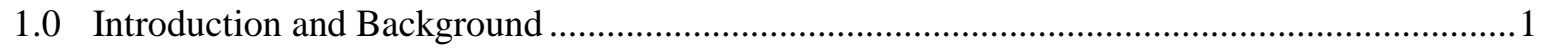

1.1 Field Testing and Case Studies ..............................................................................

1.2 Controlled Laboratory Whole-Home Testing ..............................................................

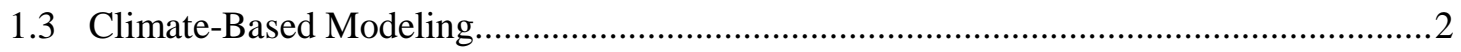

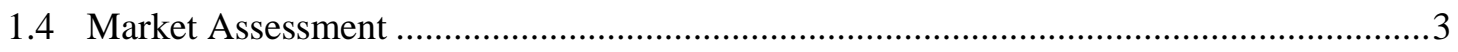

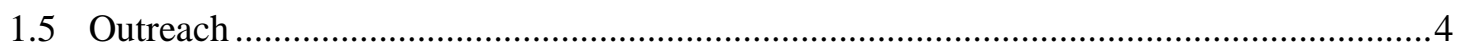

2.0 Market Transformation of Low-e Storm Windows ................................................................ 5

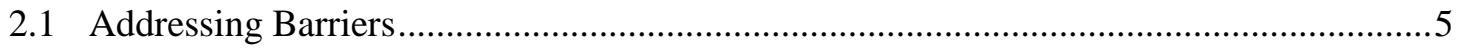

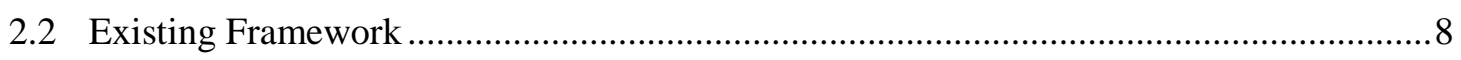

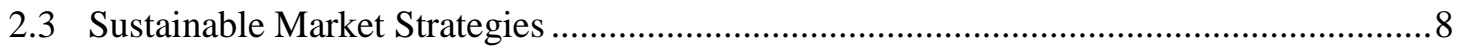

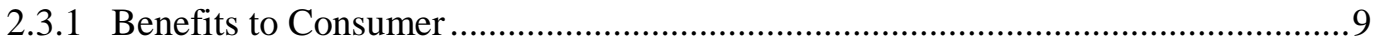

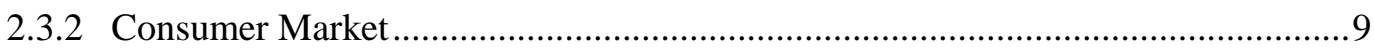

2.4 Market Transformation Opportunities............................................................................ 10

2.4.1 Home Performance Upgrades ...........................................................................11

2.4.2 Low-Income Homeowners/Renters.............................................................13

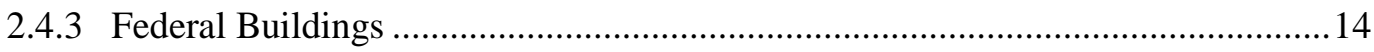

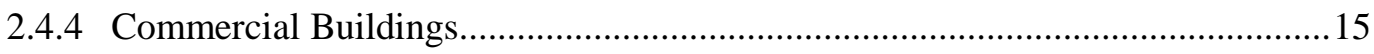

2.5 Summary of Market Transformation Strategies ...........................................................15

3.0 Market Transformation Task Plan and Goals ...................................................................17

3.1 Lab Homes Testing and Modeling ........................................................................... 18

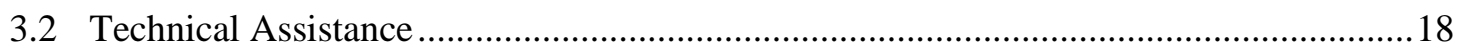

3.2.1 Codes and Standards Innovation Team .........................................................18

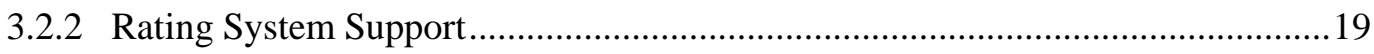

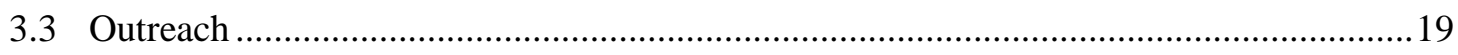

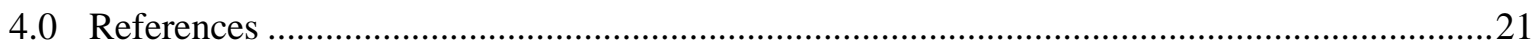




\section{Figures}

1 Overall Recommended Regions for the Use of Low-e Storm Windows Installed Over Single-Pane Windows and Double-Pane Metal-Framed Windows and the Location of Cities Included in this Analysis

2 Overall Recommended Regions for Use of Low-e Storm Windows Installed Over Double-Pane, Wood/Vinyl-Framed Windows ............................................................................. 4

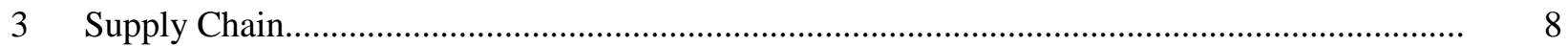

4 Number of Households with Single-Pane and Double-Pane Clear by U.S. Census Division ...... 10

\section{Tables}

1 Summarized Case Studies Focused on Low-e Storm Windows ............................................... 2

2 Barriers, Strategies, and Pathways to Market Transformation for Low-e Storm Windows ......... 7

3 Size of Market Segment and Potential Pathways to Market Transformation .............................. 17 


\subsection{Introduction and Background}

Low emissivity (low-e) storm windows/panels appear to hold promise for effectively reducing existing home heating, ventilation, and air-conditioning (HVAC) consumption. Due to the affordability of low-emissivity (low-e) storm windows and the large numbers of existing homes that have lowperforming single-pane or double-pane clear windows, a tremendous opportunity exists to provide energy savings by transforming the low-e storm window market and increasing market adoption. This report outlines U.S. Department of Energy (DOE) Building America's planned market transformation activities in support of low-e storm window adoption during fiscal year (FY) 2014 and also provides the basis for selecting these particular market transformation activities. Building America plans to continue laboratory testing of low-e storm windows to confirm and validate energy-savings in multiple climate zones. In addition, Building America will provide technical support and outreach activities to address identified market adoption barriers related to low-e storm windows.

Low-e storm windows have now been commercially available on a wide-scale since 2009; thus, the focus of DOE's support is moving toward enabling the market transformation and deployment of low-e storm windows by confirming and validating the performance of the technology and identifying and overcoming technical and market barriers to their adoption. Building America serves as a catalyst to accelerate the residential building energy-efficiency market transformation and support increasing levels of cost-effective whole-house energy savings. Previous DOE-sponsored efforts related to low-e storm window development, testing, validation, and deployment include a series of field tests and case studies, building energy modeling, a market assessment, and outreach efforts. These efforts are described below.

\subsection{Field Testing and Case Studies}

A series of laboratory tests have proven that standard low-e storm windows save energy at the component level. The performance improvements have been validated with field tests and case studies supported by DOE's emerging technologies team. The approaches and results of these field tests and case studies are described and summarized in previous reports (Hefty et al. 2013; Cort 2013) and a high-level summary of these activities is provided in Table 1.

\subsection{Controlled Laboratory Whole-Home Testing}

In a controlled whole-building experiment using twin houses, the performance of low-e storm windows over double-pane, well-sealed clear glass windows was compared between the control and experiment (Widder 2013). This study is ongoing; however, preliminary heating season data $^{1}$ (from a 2week time period) have been collected for this research project funded by Building America. The preliminary results show an average of $10.3 \%$ whole-house energy savings ( $\pm 2.3 \%$ with $95 \%$ confidence). The HVAC savings were $14.7 \% \pm 3.7 \%$. As the study progresses, more data will give this number more significance. Because the baseline windows were well-sealed, there was very little infiltration recorded in the baseline; thus, most of the savings from the storm window attachment is

\footnotetext{
${ }^{1}$ Communicated via e-mail correspondence from Sarah Widder, Program Lead for Low-e Storm Lab Home Testing, “LES Preliminary Heating Season Results,” April 10, 2013.
} 
expected to be attributable to the insulating (including low-e) properties of the storm window. Cooling season and final heating season results are forthcoming in March 2014.

\subsection{Climate-Based Modeling}

The energy savings and cost effectiveness of installing low-e storm windows over existing windows in residential homes was evaluated across a broad range of U.S. climate zones. Calculations of energy savings and cost effectiveness of low-e storm windows were conducted with two software platforms: the National Energy Audit Tool (NEAT) used by weatherization programs and RESFEN software used to compare the annual energy performance of different window options in single-family homes (Culp and Cort 2013).

Table 1. Summarized Case Studies Focused on Low-e Storm Windows

\begin{tabular}{|c|c|c|c|}
\hline Study & Sponsor & Baseline Description & Findings \\
\hline $\begin{array}{l}\text { Chicago Case Study } \\
\text { (2007) }\end{array}$ & $\begin{array}{l}\text { DOE, HUD, } \\
\text { NAHB } \\
\text { Research } \\
\text { Center, LBNL }\end{array}$ & $\begin{array}{l}6 \text { low-income homes; } \\
\text { single-pane wood } \\
\text { framed windows }\end{array}$ & $\begin{array}{l}\text { - } 21 \% \text { reduction in overall home heating load } \\
\text { - } 7 \% \text { reduction in overall home air infiltration } \\
\text { - } \quad \text { Simple payback of } 4 \text { to } 5 \text { years }\end{array}$ \\
\hline $\begin{array}{l}\text { Infrared Camera } \\
\text { Imaging }\end{array}$ & $\begin{array}{l}\text { DOE, LBNL, } \\
\text { Building Green }\end{array}$ & $\begin{array}{l}\text { Single-pane wood } \\
\text { framed windows }\end{array}$ & $\begin{array}{l}\text { Images showed that low-e storm windows performed } \\
\text { equivalently or better than new double-pane } \\
\text { replacement windows with low-e glass and argon fill }\end{array}$ \\
\hline $\begin{array}{l}\text { Atlanta Case Study } \\
\text { (ongoing 2-year study) }\end{array}$ & $\begin{array}{l}\text { DOE, } \\
\text { Quanta, } \\
\text { Larson, } \\
\text { NAHB, } \\
\text { NACG } \\
\text { Flat Glass, and } \\
\text { NSG- } \\
\text { Pilkington }\end{array}$ & $\begin{array}{l}10 \text { occupied homes; } \\
\text { single-pane wood } \\
\text { framed windows }\end{array}$ & $\begin{array}{l}\text { Ongoing, but preliminary findings suggest: } \\
\text { - } \sim 10 \% \text { heating energy reduction } \\
\text { - } \sim 8 \% \text { cooling reduction }\end{array}$ \\
\hline $\begin{array}{l}\text { Philadelphia } \\
\text { Multifamily Case Study } \\
\text { (ongoing) }\end{array}$ & $\begin{array}{l}\text { DOE, Quanta, } \\
\text { Larson, } \\
\text { NAHB, AGC } \\
\text { Flat Glass, } \\
\text { NSG- } \\
\text { Pilkington }\end{array}$ & $\begin{array}{l}2 \text { large multifamily } \\
\text { buildings; single- } \\
\text { pane, metal framed } \\
\text { windows }\end{array}$ & $\begin{array}{l}\text { Preliminary findings: } \\
\text { - } 10 \% \text { reduction in overall apartment air leakage from } \\
\text { use of new low-e storm windows (replacing old } \\
\text { clear storm windows) }\end{array}$ \\
\hline $\begin{array}{l}\text { Field Air-Leakage } \\
\text { Testing (Bronx, NY, } \\
\text { 2013) }\end{array}$ & $\begin{array}{l}\text { Steven Winter } \\
\text { Associates, } \\
\text { Quanta }\end{array}$ & $\begin{array}{l}\text { Multifamily } \\
\text { dwellings in Bronx }\end{array}$ & $\begin{array}{l}\text { Effective leakage reduction of: } \\
\text { - } 77 \% \text { for windows without air-conditioning units } \\
\text { - } 95 \% \text { for windows with air-conditioning units }\end{array}$ \\
\hline $\begin{array}{l}\text { Pennsylvania } \\
\text { Weatherization } \\
\text { technical support (2010) }\end{array}$ & $\begin{array}{l}\text { DOE, Birch } \\
\text { Point } \\
\text { Consulting } \\
\end{array}$ & $\begin{array}{l}37 \text { model homes with } \\
\text { range of window } \\
\text { types }\end{array}$ & $\begin{array}{l}\text { Modeled results for } 7 \text { climate zones: } \\
\text { - } 12 \% \text { to } 33 \% \text { overall HVAC savings }\end{array}$ \\
\hline \multicolumn{4}{|c|}{$\begin{array}{l}\text { (a) Quanta Technologies, Inc., Malvern, Pennsylvania. } \\
\text { (b) Larson Manufacturing Company, Brookings, South Dakota. } \\
\text { Sources and documentation for case study results include Drumheller et al. (2007); Quanta Technologies (2013); Zalis et. al. } \\
\text { (2010). } \\
\text { AGC = Asahi Glass Company; HUD = U.S. Department of Housing and Urban Development; LBNL = Lawrence Berkeley } \\
\text { National Laboratory; NAHB = National Association of Home Builders. }\end{array}$} \\
\hline
\end{tabular}

Both exterior and interior low-e storm windows/panels installed in conjunction with three different primary window types were evaluated in 22 different cities across all eight International Energy Conservation Code (IECC) climate zones. Both regular low-e glass and solar control low-e glass, which 
decreases solar heat gain in addition to decreasing heat transfer through the glass, were included in the analysis. The NEAT analysis used 39 model homes, and the RESFEN analysis used two model homes.

Low-e storm windows were found to always be cost effective when installed over single-pane windows and double-pane, metal-framed windows in climate zones 3 through 8 . The savings-toinvestment ratio (SIR) ranged from 1.2 to 3.2 across the different locations analyzed. The average source energy savings ranged from 21 to $36 \%$ with a simple payback period of 3.7 to 10.2 years across climate zones 3 through 8 . The use of solar-control, low-e storm windows is recommended in climate zone 3 , and may also be considered in warmer parts of zone 4 where cooling degree days exceed heating degree days. The use of regular low-e storm windows is recommended in zones 4 through 8 (see Figure 1 and Figure 2).

In addition, the incremental cost for using low-e glass versus clear glass was found to be cost effective in all climate zones over all window types with an average payback period of 2 to 4 years. This indicates that, when a homeowner chooses to install a storm window or interior window panel for reasons other than just energy savings (e.g., increased comfort, noise reduction, window protection, reduced air leakage, etc.), the use of low-e glass is recommended regardless of location.

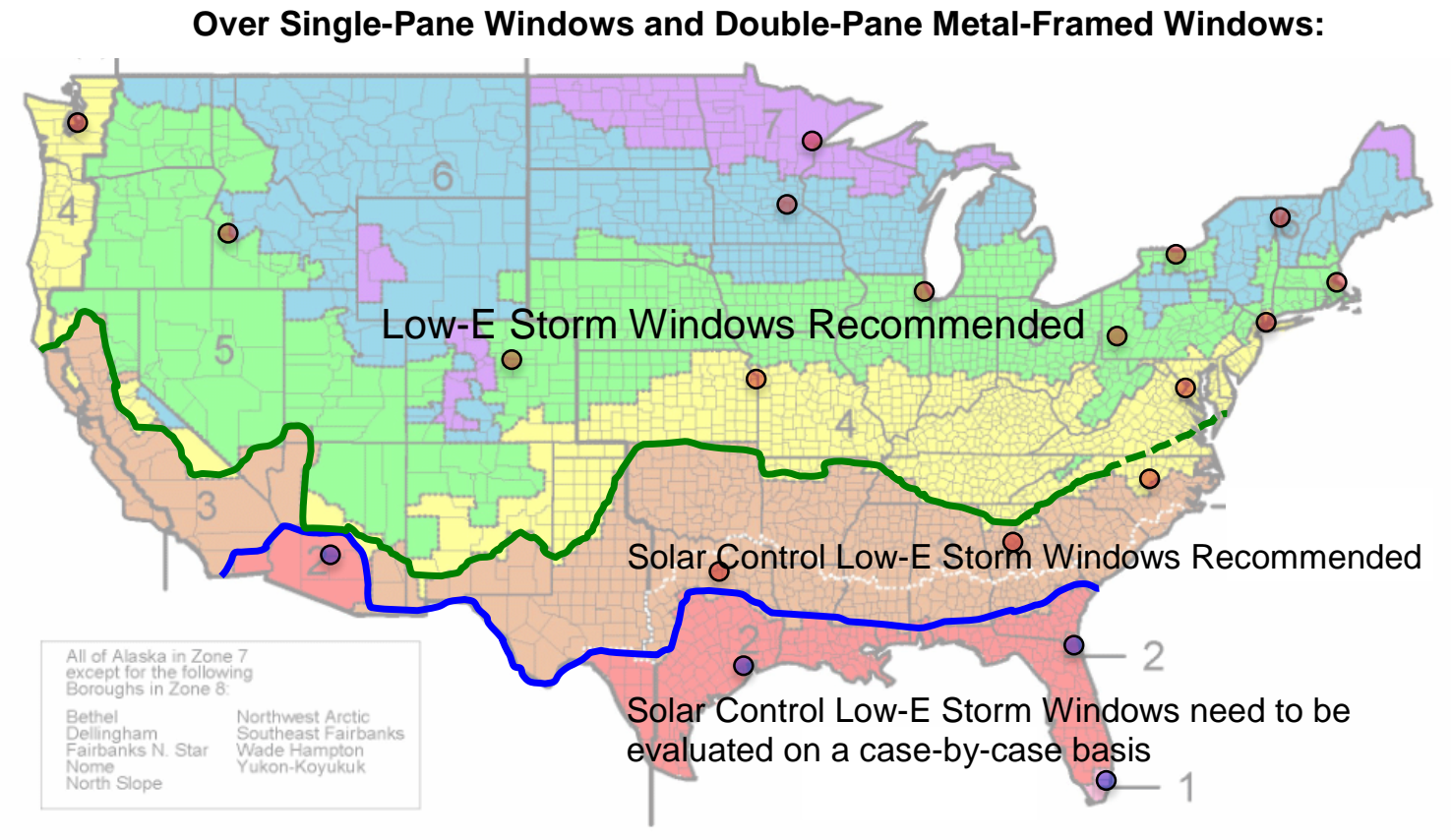

Figure 1. Overall Recommended Regions for the Use of Low-e Storm Windows Installed Over SinglePane Windows and Double-Pane Metal-Framed Windows and the Location of Cities Included in this Analysis

\subsection{Market Assessment}

To assess the marketability and market adoption potential of low-e storm windows, Building America sponsored a market assessment, which examined and characterized the benefits and costs of the low-e 
storm windows, the size and characteristics of likely target markets, the potential pathways to reach these markets, possible market barriers, and the likelihood of overcoming these barriers. A number of promising market transformation pathways were identified, including existing weatherization assistance programs, utility energy-efficiency incentive programs, federally sponsored energy-efficiency retrofit programs, standards and rating organizations, and federal building energy-efficiency mandates and programs. This FY 2014 program plan is informed by many of the findings of the 2013 market assessment (Cort 2013).

\section{Over Double Pane Wood/Vinyl Framed Windows:}

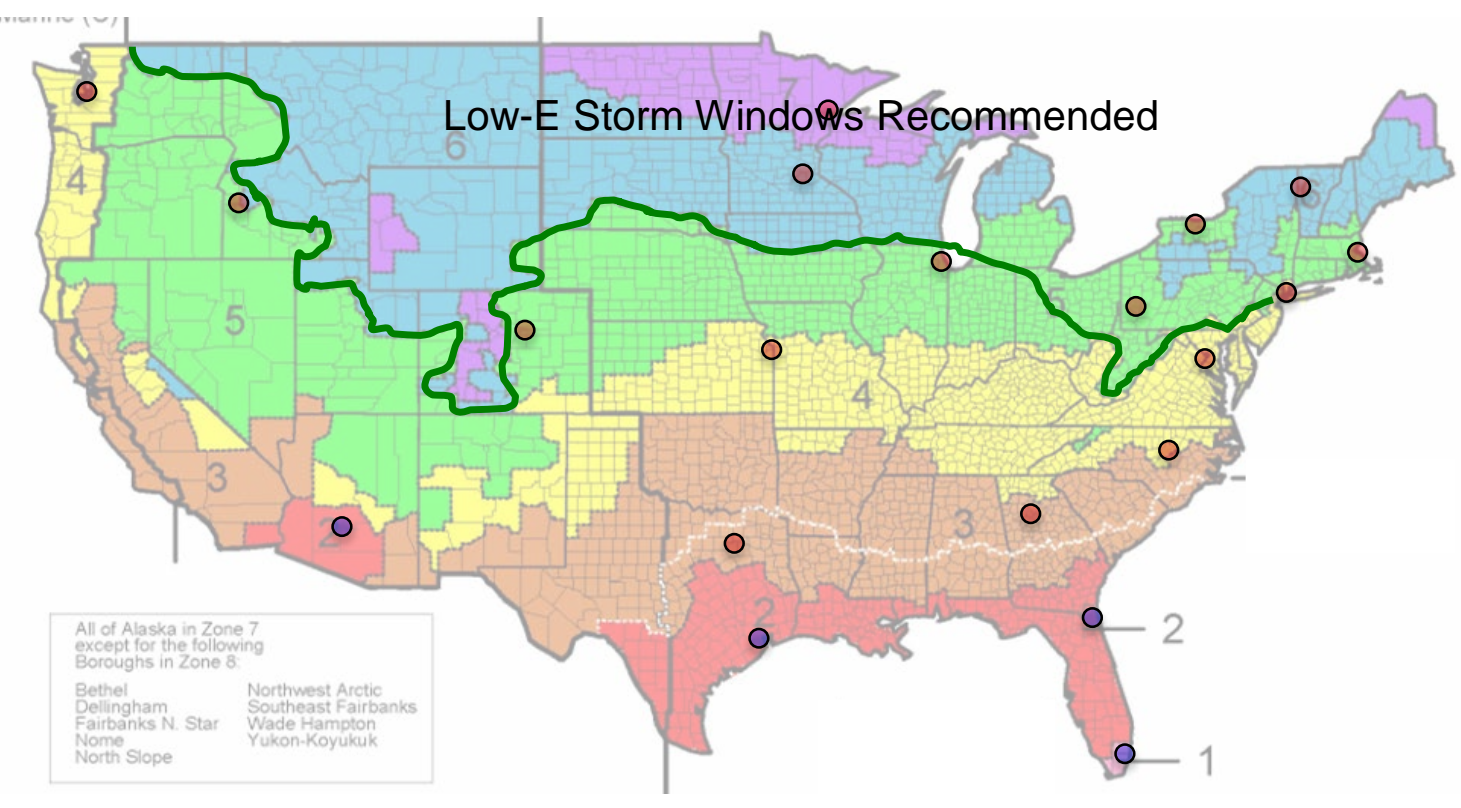

Figure 2. Overall Recommended Regions for Use of Low-e Storm Windows Installed Over DoublePane, Wood/Vinyl-Framed Windows. The region where low-e storm windows are recommended will be larger than shown for homes using propane or electrical resistance heating, or those that have particularly leaky windows. Points indicated on the map show the location of cities included in this analysis.

\subsection{Outreach}

Building America-led outreach efforts related to low-e storm window adoption were conducted with the Consortium for Energy Efficiency (CEE) to develop guidance for utilities related to window attachments. A weatherization brochure was also developed, which outlined the benefits of low-e storm windows in terms of energy savings as a weatherization measure (Hefty and Gilbride 2013). 


\subsection{Market Transformation of Low-e Storm Windows}

The building research conducted by the Building America Program is based on the use of collaborative, industry-based teams that integrate across supply chains, business practices, and stakeholders to deliver products of value and minimize overall costs and risks. The overall goal of market transformation is to increase the share of energy-efficient products and services within targeted markets. Market transformation efforts also must recognize the importance of working with key market playersmanufacturers, distributors, retailers, and consumers - for any type of intervention. In addition, these market changes should lead to sustained increases in the adoption of energy-efficient products, services, and/or practices. The market transformation plan for Building America's Low-e Storm Window Adoption Program will be based on the following key principles (as documented by Nadel and Geller 1996):

- Interventions are direct responses to identified market barriers.

- Any new products, services, or practices related to transforming the market will appear within already existing program and market frameworks, using partnerships between government, the private sector, and other stakeholders that influence the buildings market structure and function.

- Efforts will focus on benefits that are inherently sustained because the market changes do not require further interventions. Competitive market forces drive energy-efficiency gains.

\subsection{Addressing Barriers}

Although the cost and performance attributes of low-e storm windows set the stage for wide-scale market success, some significant barriers to deployment have been noted based on early experience in the market, as documented in the 2013 Pacific Northwest National Laboratory (PNNL) report, Low-E Storm Windows: Market Assessment and Pathways to Market Transformation (Cort 2013).

1. Identity crisis. End-users and energy-efficiency program administrators appear to be confused about storm windows, low-e coatings, and their classification as an energy-efficiency measure. Storm windows seem to fall between the cracks of being windows and insulation (e.g., they have no ratings from the National Fenestration Rating Council (NFRC), which rates the performance of windows and no rating as an insulation measure). Weatherization program administrators often categorize storm window installations in the same category as window replacements. Because window replacements are usually too costly to qualify as weatherization measures, by association, storm windows are also dismissed as qualified measures. To contend with this issue of identity, some window attachment manufacturers have started to refer to storm windows as storm panels to distinguish them from prime windows and previous generations of storm windows.

2. Stigma. Storm windows suffer from an image problem due, in part, to some of the more homely, inoperable storm windows of the past. Further, previous generations of storm windows were typically only installed during the winter and taken down for the remainder of the year, making their installation a tedious annual chore. Previous generations of storm windows were not always well sealed, became dirty easily, and condensation built up on them. Despite the improvements that have been made to the sealing, framing, aesthetics, and operability of storm windows, the stigma persists and potentially hampers market uptake. Storm windows may also be thought of by some as lowerclass quick-fix measures for a home. 
3. Not recognized by rating systems. Despite the proven energy savings of low-e storm windows, no standard rating system or energy-efficiency label exists for storm windows. As previously mentioned, NFRC provides ratings for windows, but not for storm windows. This affects other areas, such as building energy standards and codes, federal tax energy-efficiency rebates, and various energy-efficiency programs that reference the product ratings of NFRC or other reputed organizations as criteria for meeting requirements or qualifying for funding and programs. Although Energy Star has labels for windows, there is no Energy Star label for storm windows. One industry representative mentioned that one of the most frequently asked questions by potential low-e storm window customers was whether or not the product has an Energy Star label. Consumers have come to rely on the Energy Star label to guide their decision-making process related to energy-efficient products. The absence of this label and rating potentially hamper the market uptake of this product. Likewise, although it is a newer rating system, DOE's Home Energy Score does not take into account the influence of storm window attachments on energy consumption and it does not include low-e storm windows (or any window attachments) in its list of recommended improvements.

4. Potential code barriers. Although no specific building code barriers have been identified, this is an area to continue to watch to ensure no code barriers arise that could impede growth in certain markets. As more third-party installations occur, and if installations of storm windows occur during major renovations, code barriers may surface. Both the IECC and ASHRAE ${ }^{2} 90.1$ provide allowances for storm windows installed over existing windows, because they improve energy performance. Furthermore, the new ASHRAE 90.1-2013 requires that any storm windows include low-e coated glazing unless the existing window already includes low-e glass. However, installations of storm windows in certain hazardous locations defined by the building code require special tempered glass that adds extra cost, such as interior panels in overhead glazing or in bathrooms near a bathtub. Certain federal buildings may also have certain blast-resistant requirements that require laminated glazing and special anchorage.

5. Do-it-yourself (or not). One manufacturer noted that $80 \%$ of storm window installations are do-ityourself projects. In some marketability respects this is good news, because it implies low-cost and easy installation. However, this indicates that third-party installation contractors and installers are not common and that this potential "sales force" has not been well developed. Further, many do-ityourself projects are put off for another day or simply never happen. If storm windows are fixed in the do-it-yourself category, they may fall victim to procrastination and installation of storm windows will only occur after the homeowner gets around to fixing the hole in the fence, programming the thermostat, and cleaning out the closets.

6. Industry structure. Most storm window manufacturers also manufacture prime windows. Some in the industry have noted that the profit margin on prime window replacement is greater than that for storm windows; thus, the majority of manufacturers do not have a great incentive to advocate for storm windows (Cort 2013). Instead they classify them as a secondary product, available on a customized basis for special orders only. Further, due to the customized nature of this product, there are a number of smaller storm window manufacturers that have only regional distribution networks. There is only one storm window manufacturer with national distribution that is not also a prime

\footnotetext{
${ }^{2}$ The American Society of Heating, Refrigerating and Air Conditioning Engineers (ASHRAE) is referenced in this report to represent the larger commercial building energy standard developing body referred to as ANSI/ASHRAE/IES, where ANSI is the American National Standards Institute and IESNA is the Illuminating Engineering Society.
} 
window manufacturer (Larson Manufacturing Company). Most of these smaller regional manufacturers currently only manufacture clear storm windows.

Some of these barriers, such as industry structure and persistent stigma issues, may not be easily addressed by Building America efforts; however, other barriers could be overcome by Building America's research, outreach, education, and technical assistance programs. These barriers and potential strategies to overcome these barriers are summarized in Table 2 and discussed in Section 2.4.

Table 2. Barriers, Strategies, and Pathways to Market Transformation for Low-e Storm Windows

\begin{tabular}{|c|c|c|}
\hline Barriers & Strategies & Pathways “Core Customers” \\
\hline Identity crisis & $\begin{array}{l}\text { Determine and validate performance in multiple climate zones. } \\
\text { Tailor analysis and tools to WAP criteria to integrate low-e } \\
\text { storm windows and weatherization measures. Disseminate } \\
\text { information to relevant stakeholders, leveraging credibility } \\
\text { from Building America, DOE, and national laboratories. } \\
\text { Continue interactions and participation in CEE working groups } \\
\text { and outreach efforts. Follow initial contacts with utilities. }\end{array}$ & $\begin{array}{l}\text { Codes and rating } \\
\text { organizations, WAP, utilities, } \\
\text { and CEE }\end{array}$ \\
\hline Stigma & $\begin{array}{l}\text { Building America should continue in its role as an honest } \\
\text { broker of research and information. It should determine and } \\
\text { validate the performance of low-e storm windows, including } \\
\text { how different circumstances and climate regions may affect } \\
\text { this performance, tailoring modeling tools to integrate low-e } \\
\text { storm window performance. Building America should } \\
\text { effectively disseminate this information to appropriate } \\
\text { audiences. }\end{array}$ & $\begin{array}{l}\text { Utilities, CEE, WAP, and } \\
\text { federal agencies }\end{array}$ \\
\hline $\begin{array}{l}\text { Not recognized } \\
\text { by rating systems }\end{array}$ & $\begin{array}{l}\text { Continue to support working groups focused on establishing } \\
\text { rating system for low-e storm windows. Work with Energy } \\
\text { Star and Home Energy Score teams. }\end{array}$ & $\begin{array}{l}\text { Codes and Rating } \\
\text { Organizations (NFRC, } \\
\text { Building America’s Codes } \\
\text { and Standards Innovation } \\
\text { (CSI) team, Energy Star } \\
\text { (EPA/DOE), Home Energy } \\
\text { Score (DOE) }\end{array}$ \\
\hline $\begin{array}{l}\text { Potential code } \\
\text { barriers }\end{array}$ & $\begin{array}{l}\text { Use Building America's CSI team to monitor code activities to } \\
\text { ensure no code barriers arise to hinder use of low-e storm } \\
\text { windows. }\end{array}$ & Building America’s CSI team \\
\hline $\begin{array}{l}\text { Do-it-yourself } \\
\text { confinement }\end{array}$ & $\begin{array}{l}\text { Develop third-party contractors through outreach, education, } \\
\text { and technical assistance efforts directed toward WAP, Home } \\
\text { Performance with Energy Star (HPwES), and FEMP } \\
\text { deployment efforts. }\end{array}$ & WAP, HPwES, FEMP \\
\hline $\begin{array}{l}\text { Industry } \\
\text { structure }\end{array}$ & $\begin{array}{l}\text { No specific strategy identified. If the demand for low-e storm } \\
\text { windows exists, the industry will expand; thus, general } \\
\text { deployment efforts would be the best approach for addressing } \\
\text { this barrier. }\end{array}$ & \\
\hline
\end{tabular}




\subsection{Existing Framework}

Based on the market segments and the pathways identified for each segment, the market transformation supply chain should include utilities (i.e., sponsors of regional energy-efficiency programs), retailers and distributors of low-e storm windows, weatherization assistance programs (WAPs), government agencies that manage residential stock (e.g., General Services Administration [GSA] and U.S. Department of Defense [DOD]), and standards and rating organizations. On the supply chain (Figure 3) these would represent the core customers of research and deployment related to low-e storm windows and they act as the primary contacts with the end customers. The supply chain sales force for deployment would include stakeholders with a business interest to promote the performance and market research related to low-e storm windows (e.g., storm window manufacturers, installers and home performance contractors, and Federal Energy Management Program [FEMP]). The sales force would also include energy-efficiency consortiums (e.g., CEE), Building America teams, Better Building (BB) teams, and for commercial end customers, DOE's Commercial Buildings Integration teams.

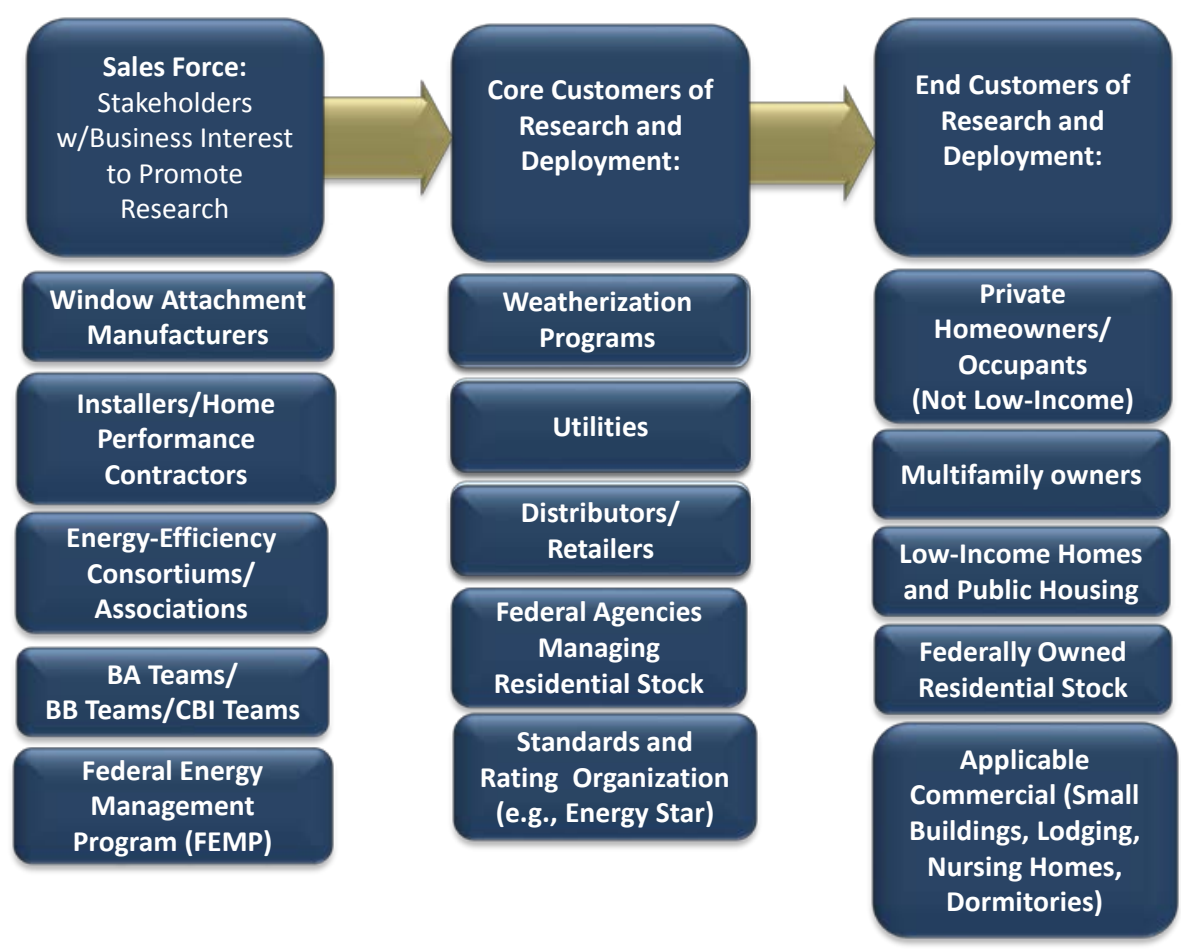

Figure 3. Supply Chain (including contact points with end customer)

\subsection{Sustainable Market Strategies}

In order for the benefits of market transformation efforts to be sustained, there must be an inherent benefit of the energy-efficient technology to the consumer, a commercially viable market within which to work, and the potential to grow this market further. The commercial viability of the product should not be dependent on continuing market transformation intervention and competitive market forces drive energy-efficiency gains. 


\subsubsection{Benefits to Consumer}

Low-e storm windows were found to always be cost effective when installed over single-pane windows and double-pane, metal-framed windows in six of the eight continental U.S. climate zones (Culp and Cort 2013). The SIR ranged from 1.2 to 3.2 across the different locations analyzed, with an average source energy savings ranging from 21 to $36 \%$. The payback for low-e storm window installations can range from 3 to 11 years depending on climate, fuel prices, and the condition of the existing window and home. The upfront capital costs range from around $\$ 70$ to $\$ 150$ per window, which is approximately one-third of the cost of a replacement window. Installation can occur with no upfront monetary costs as a do-it-yourself project or be contracted out to a professional for approximately $\$ 60$ per window.

In addition to the energy-saving benefits, low-e storm windows have marketable benefits such as added comfort and noise reduction. Participants in the Atlanta Case Study listed improved aesthetics and comfort as the most valued benefits of the storm window applications. From a marketability standpoint, aesthetic appeal is critical for such an architecturally important, visible retrofit measure (Quanta Technologies 2013).

\subsubsection{Consumer Market}

In terms of energy savings, the homes and buildings that realize the greatest benefits from the installation of low-e storm windows are those with single-pane, low-performing, leaky windows. DOE's 2009 Residential Energy Consumption Survey (RECS) estimated that approximately 47.2 million (or $\sim 40 \%$ ) of existing residential homes have single-pane windows (DOE-EIA 2009). Although some of these homes may have storm windows attached, the vast majority would be older storm windows with higher air leakage and without high-performing low-e glass. Based on preliminary data from the 2013 PNNL Lab Homes study, residential homes with double-pane clear windows (i.e., no low-e coating) would also realize significant energy-savings benefits from the installation of low-e storm windows (Cort 20130. Based on RECS data and replacement window shipment data, approximately 46 million homes have windows with double-pane clear glass (AAMA 2012). ${ }^{3}$

Although the field testing and early target markets for low-e storm windows have been directed toward the colder, more heating-dominated northern states, the installation of a low-e storm window also reduces the solar heat gain coefficient, which provides a cooling benefit by reducing radiant heat gains. Thus, the potential target market for this technology could include the 93 million U.S. homes with singlepane windows and double-pane windows without low-e coatings. Figure 4 breaks out the number of households with single-pane and double-pane clear windows by Census region. Each region has a similar number of existing homes with either single-pane or double-pane clear windows (ranging from 17 to 20 million per region).

Traditionally, residential homes have made up the market for storm windows; however, some commercial applications could be considered. Low-e storm windows could be an appropriate retrofit measure for small commercial buildings with poorly performing windows, historic buildings, and

\footnotetext{
${ }^{3}$ Although the 2009 RECS did not include estimates of double-pane clear windows, the 2005 RECS survey estimated 50.6 million homes with double-pane clear windows (DOE-EIA 2005). The current estimate is based on estimates of prime window replacements (AAMA 2012) during the time frame and window trends between the 2005 and 2009 RECS.
} 
commercial buildings that house residents (e.g., nursing homes, hotels and motels, and dormitories). Preliminary findings from the DOE-funded multifamily case study in Philadelphia demonstrated energy benefits using Quanta Technologies’ interior low-e storm windows for large apartment buildings (Quanta Technologies 2013). For larger building applications where the windows are a similar size throughout, mass application of interior low-e storm windows can be a cost-effective option for reducing HVAC loads.

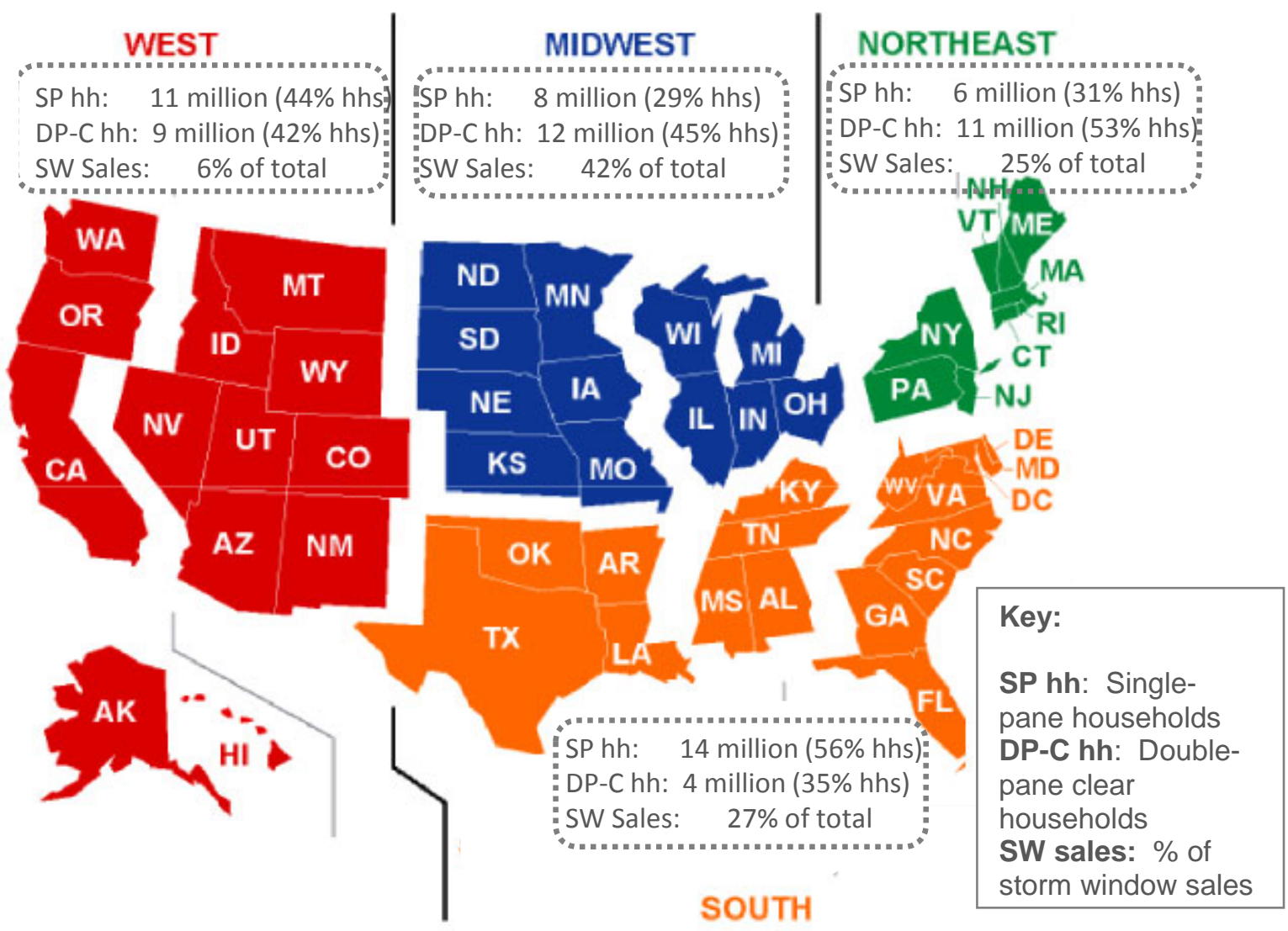

Figure 4. Number of Households with Single-Pane and Double-Pane Clear by U.S. Census Division. Percentage of total storm window sales (2012) estimated by Census Division ${ }^{4}$

\subsection{Market Transformation Opportunities}

Based on the barriers, existing framework and partnerships, and consumer benefits identified in the previous sections of this report, the following targeted markets and market transformation pathways and strategies are identified for low-e storm windows.

\footnotetext{
${ }^{4}$ Regional splits for storm window sales provided by Larson Manufacturing, 2012. All other estimates were based on RECS 2005, RECS 2009, calibrated with AAMA 2012 replacement window sales estimates.
} 


\subsubsection{Home Performance Upgrades}

An estimated 8 million storm window units are sold each year. Assuming approximately 15 windows ${ }^{5}$ per home, 8 million storm window units would cover the windows of approximately 533,000 single-family homes. Currently, only a small fraction ${ }^{6}$ of these sales are low-e storm windows; however, low-e storm window sales have been growing as a fraction of total sales since becoming commercially available in 2009. It is unclear whether these storm window sales are associated with any particular energy-efficiency incentive programs; however, a search of the Database of State Incentives for Renewables and Efficiency (DSIRE) ${ }^{7}$ suggests that 18 states have at least 26 utility-sponsored incentive programs between them that explicitly identify storm windows as qualified measures. Thus, it is likely that some of these storm window sales are at least partially funded by utility-sponsored energy-efficiency programs.

Additional energy-efficiency programs could also influence the sale of storm windows, such as Home Performance with ENERGY STAR (HPwES), which is a federally supported residential energyefficiency program focusing on upgrading the existing housing stock with energy-efficiency measures. Considering the current regional distribution of existing storm window sales and the do-it-yourself nature of installations, combined with the somewhat limited nature of efficiency programs focusing on window attachments, it seems likely that most of the existing storm window sales are simply part of the estimated $\$ 12$ billion spent on home improvements related to windows and doors in each year (approximately 15\% of which includes do-it-yourself projects) (JCHS 2013).

Market Segment. In general, the specific market segment involved in energy-performance upgrades includes single-family homes that are typically middle to higher income households (i.e., not low income). This segment also includes multifamily homes (other than U.S. Department of Housing and Urban Development [HUD] subsidized multi-family housing).

Pathways to Market Segment. A number of paths could be pursued to tap the mainstream home performance industry, which would eventually lead to privately owned homes (whether owners of rental stock or homeowner-occupied housing). These would include reaching out to the following groups and programs:

- Retailers (big-box and independent dealers). Most storm windows are purchased by individuals from either big-box retailers or independent dealers. Considering that $80 \%$ of storm window installations are do-it-yourself projects, regardless of whether the action is incentivized by a program, the contact to the end customer comes through the retailer.

- Utility Incentive Programs. At least 18 states have utility programs that explicitly identify storm windows as energy-efficiency measures that qualify to receive rebates or forms of incentives from the utilities or state programs. Although it is not clear what impact these programs have had on storm window sales, this clearly is a pathway that could be pursued to reach end customers. Furthermore, these programs only address storm windows in a generic sense, and do not specifically require low-e storm windows. Therefore, there is the potential to modify current programs to require or incentivize

\footnotetext{
${ }^{5}$ Based on “Characteristics of a Typical Single-Family Home,” from 2011 Building Energy Databook , Table 2.2.7 (DOE 2011)

${ }^{6}$ Estimated to be less than $10 \%$ in 2011 from an informal industry estimate. This number has been growing. No current estimate is available.

${ }^{7}$ DSIRE database search available online at: http://www.dsireusa.org/.
} 
low-e storm windows and capture higher energy performance benefits. The incentive could be structured to offset any incremental cost of low-e storm windows compared to standard clear glass storm windows, to ensure that when a consumer purchases a storm window, it is a low-e storm window. This is also a pathway with great potential for growth to establish programs in the 32 states that do not include programs explicitly directed toward storm windows.

- Energy-Efficiency Retrofit and Weatherization Programs. In addition to utility-sponsored incentive programs, a number of federally sponsored programs promote energy-efficiency in existing buildings and weatherization measures. In particular, HPwES is focused on improving the energy efficiency of existing homes by facilitating whole-house energy assessments through a network of qualified contractors. HPwES is a national program administered by DOE and the U.S.

Environmental Protection Agency (EPA) and managed at the state or regional level. Although this program focuses on whole-house retrofits, it also includes a prescriptive approach, which lists eligible measures. Inclusion in the list of eligible measures could be beneficial for the market adoption of low-e storm windows. In a 2012 survey of 7 home performance contractors that worked with HPwES, when asked to categorize the types of home performance measures, the contractors did not list the installation of storm windows in any of projects completed in a 3-year time frame, despite the fact that a majority of the projects included air sealing and insulation activities (contractors noted that over 2000 projects were completed during the timeframe) (PNNL 2012).

There are other programs promote weatherization measures in existing homes. The largest weatherization program is DOE's Weatherization Assistance Program (WAP), which provides technical assistance and formula grants to state and local weatherization agencies and includes a network of approximately 970 local agencies that provide trained crews to perform weatherization services for eligible low-income households in single-family homes, multifamily dwellings, and mobile homes. These programs assist market transformation not only in the retrofits directly carried out as part of the programs, but also through their training and networking with regional home performance and weatherization contractors.

- Standards and Energy-Efficiency Rating Organizations. Standards and energy-efficiency ratings can drive the market for energy-efficient products. One storm window manufacturer noted that the most frequently asked question about low-e storm windows was whether or not they had an Energy Star label. Consumers have come to rely on this label to inform their decision-making for energyefficiency products. The absence of a label may make them question performance in terms of energy efficiency. Likewise, there is not yet a U-factor or R-value rating from the NFRC or similar organization that is directed toward storm windows, which may also leave retailers and consumers to question whether low-e storm windows are worthwhile investments. The Home Energy Score is a relatively new rating system developed by DOE’s Building Technologies Office, which assigns a score to an existing home, similar to a vehicle's mile-per-gallon rating. The Home Energy Score allows homeowners to compare the energy performance of their homes to other homes nationwide. It also provides homeowners with suggestions for improving their homes' efficiency. Currently, the Home Energy Score does not take into account the influence of storm windows on energy consumption and its scoring system does not include storm windows in its list of suggested energyefficiency improvements. 


\subsubsection{Low-Income Homeowners/Renters}

Approximately 25\% of existing residential households are at or below $150 \%$ of the poverty level (referred to in this report as low-income). Approximately $44 \%$ of low-income households are owneroccupied. Low-income households typically spend $17 \%$ of their total annual income on energy costs, compared with $4 \%$ for other households (USCB 2012). Although these homes are often in need of energy-efficiency upgrades that could reduce their energy bills, the occupants are often not able to afford the upfront costs needed to implement upgrades. ${ }^{8}$

To address the weatherization retrofit needs of lower income households, DOE's WAP administers grants by providing technical assistance and formula grants to state and local weatherization agencies. DOE leverages funding for activities conducted under the WAP with contributions from the Low-Income Home Energy Assistance Program at the U.S. Department of Health and Human Services, energy utilities, state agencies, private companies, and Petroleum Violation Escrow funds. These contributions can take the form of direct project-targeted funding or in-kind contributions (e.g., staff, research-in-kind, facilities, or other nonmonetary resources).

Because of their affordability and energy savings, low-e storm windows are well suited to meet the needs of weatherization and WAP requirements. Federally funded WAPs typically have a rather rigid list of weatherization measures that qualify as part of their programs based on a SIR greater than 1 . Window replacement is not a qualifying option in most all cases simply because of the high first cost involved with replacement. However, in most cases, low-e storm windows can achieve this higher SIR, which makes the weatherization program a good potential avenue for market transformation. Initial calculations using the NEAT show SIR values ranging from 1.3 to 3.2 in central and northern climates, which means that storm windows would potentially meet the criteria to qualify for WAP funding (Zalis et al. 2011). In south-central zones, qualifying SIR values can also be achieved by using appropriate glass that provides solar control.

Market Segment. The market includes households eligible for federal assistance. Households categorized as eligible for federal assistance have a household income below the federal maximum standard of $150 \%$ of the poverty line or $60 \%$ of the statewide median income, whichever is higher. Individual states can set their standard at a lower level than the federal maximum. Approximately 30 million eligible low-income homes qualify for weatherization assistance.

Pathway to Market Segment. Two primary programs could serve as pathways to address the window retrofit needs of low-income households. These include WAP and HUD.

- Weatherization Assistance Program. Regional weatherization administrators accepting grant money from WAP develop their own sets of criteria and weatherization measures, suited to their climates. Since its inception, WAP has assisted in the weatherization of approximately 6.4 million low-income households. As part of the 2009 American Recovery and Reinvestment Act, WAP received a significant infusion of funding to weatherize low-income homes. Nearly 790,000 homes were weatherized with this funding. As part of its low-e storm window adoption program, DOE has funded projects that examine low-e storm window cost and performance in terms of the weatherization cost-effectiveness and modeling criteria. Low-e storm windows appear to meet the

\footnotetext{
${ }^{8}$ From Weatherization and Intergovernmental Program website and factsheet: http://www1.eere.energy.gov/wip/pdfs/wap_factsheet.pdf.
} 
criteria. The market adoption of low-e storm windows increased in Pennsylvania when low-e storm windows were integrated into the priority list.

- Housing and Urban Development. HUD oversees 1.12 million federally owned public housing units, locally administered by about 3,100 public housing agencies. Public housing serves lowincome households - $40 \%$ are extremely low-income, with incomes no greater than $30 \%$ of the local median incomes. Although many of the HUD houses are in need of energy-efficiency upgrades, weatherization, and repairs, very limited funding is allocated to address these needs. In 2009, HUD and DOE signed a Memorandum of Understanding promising greater cooperation in weatherizing the multifamily housing stock. To that end, a revised set of guidelines was issued by DOE that makes it easier to weatherize HUD housing by assuming that certain HUD units would be deemed qualified for weatherization.

Possible Alternative Pathway (Non-Federal). As budgets for weatherization assistance are reduced, it may be worthwhile to consider other, non-profit organizations that focus on home improvements for low-income households (e.g., Rebuilding Together, Habitat for Humanity, Enterprise Community Partners, and local initiatives). Organizations that focus on elder/senior care might also be appropriate considering that $44 \%$ of elderly (65 and older) households are classified as $200 \%$ of poverty level or less (USBC 2012).

\subsubsection{Federal Buildings}

Although the vast majority of the residential building stock is privately owned, a portion is owned by the government. Federally-owned residential stock primarily includes military housing and barracks. In an effort to reduce energy consumption in the federal sector, which is the nation's single largest energy consumer, a number of laws and Executive Orders have been enacted over the years to establish requirements and direct the reduction of energy and water consumption in federal facilities. The Energy Policy Act of 2005 (EPAct 2005) and Title IV, Subtitle C of the Energy Independence and Security Act of 2007 (EISA) provide the legislative foundation for other guidance and Executive Orders that set goals for energy-efficiency improvements in federal facilities.

Market Segment. Applicable federally-owned buildings: military housing, army barracks, dormitories, and Veterans Administration patient facilities.

Pathway to Market Segment. Although DOD and GSA are the largest "landlords" of federallyowned residential buildings, building energy management activities are coordinated through DOE's FEMP:

- FEMP. FEMP is charged with facilitating the federal government's implementation of energy management and investment policies and assisting agencies in meeting EPAct/EISA requirements and meeting energy-saving goals. FEMP works with other agencies (e.g., GSA, DOD), which act as landlords for a substantial portion of the government building stock, to implement energymanagement activities. Any active market transformation activities related to transitioning government-owned residential stock would need to work with these agencies.

- Energy Star (DOE/EPA). The Energy Star label is referenced heavily in many of the executive orders and guiding principles that direct energy management in the federal sector. Although Energy Star labels are used to identify higher performance replacement windows, storm windows do not 
carry Energy Star labels. Market transformation activities related to low-e storm windows should address the fact that low-e storm windows do not have an Energy Star label.

\subsubsection{Commercial Buildings}

Some of the case studies related to low-e storm windows (e.g., the Philadelphia Multifamily Case Study) demonstrated energy savings from low-e storm windows in high-rise commercial buildings. Interior applications of storm windows could benefit commercial buildings that house residents such as nursing homes, assisted-living facilities, and dormitories. Low-e storm windows could also be appropriate retrofit measures for small commercial buildings that have poorly performing windows and historic buildings that have building code restrictions that limit window replacement. Because this report is primarily focused on Building America's role in transforming the market, which is focused more on residential buildings, the commercial market segment is not thoroughly assessed or characterized.

Market Segment. Applicable commercial buildings (e.g., dormitories, nursing homes, assistedliving facilities, historic institutional buildings, and small commercial buildings [under $5,000 \mathrm{ft}^{2}$ ]) could benefit from the application of low-e storm windows.

\section{Summary of Market Transformation Strategies}

Although market transformation can take a number of different forms, based on the market segments and pathways to these markets characterized in Section 2.4 and the barriers to market adoption identified in Section 2.2, a number of research areas, outreach efforts, and technical assistance may serve as effective strategies for transforming the market for low-e storm windows (see Tables 2 and Table 3). 



\subsection{Market Transformation Task Plan and Goals}

Based on the identified barriers and existing market framework and partnerships, Building America's low-e storm window adoption plan includes research, technical support, and outreach efforts targeting the market segments and "core customers" presented in Table 3.1.

Table 2. Size of Market Segment and Potential Pathways to Market Transformation

\begin{tabular}{|c|c|c|}
\hline $\begin{array}{c}\text { Targeted } \\
\text { Market Segment }\end{array}$ & $\begin{array}{l}\text { Size of Market/ } \\
\text { How to Reach Market }\end{array}$ & $\begin{array}{l}\text { “Core Customers” of Building } \\
\text { America Market Research (Pathway } \\
\text { to Market Transformation) }\end{array}$ \\
\hline $\begin{array}{l}\text { Privately owned } \\
\text { mid- and high- } \\
\text { income homes } \\
\text { (single-family } \\
\text { and } \\
\text { multifamily) }\end{array}$ & $\begin{array}{l}\text { - This market could grow if more direct utility } \\
\text { incentive programs were put into place and programs } \\
\text { such as Energy Star were to include low-e storm } \\
\text { windows (On average about 1-2\% of homes perform } \\
\text { energy-related retrofits.) } \\
\text { - This market could grow if programs targeting } \\
\text { residential retrofits, such as HPwES and BB included } \\
\text { directed education/training and outreach efforts } \\
\text { toward low-e storm windows (HPwES retrofit } \\
\text { 50,000 homes in 2011). } \\
\text { This market could grow if Building America teams } \\
\text { focusing on retrofits included focus on low-e storm } \\
\text { window attachments as part of overall strategies. }\end{array}$ & $\begin{array}{l}\text { - Utilities (utility-sponsored } \\
\text { weatherization and incentive } \\
\text { programs directed toward energy- } \\
\text { efficiency of the enclosure) } \\
\text { - Standards and rating systems such } \\
\text { as Energy Star could have a } \\
\text { influence on the retrofit market by } \\
\text { establishing a program for window } \\
\text { attachments. } \\
\text { - Building America teams working } \\
\text { in climate zones } 3 \text { through } 8 \\
\text { include low-e storm windows as } \\
\text { part of retrofit strategy. }\end{array}$ \\
\hline $\begin{array}{l}\text { Low-income } \\
\text { homes }\end{array}$ & $\begin{array}{l}\text { - The size of this market is largely influenced by the } \\
\text { size and structure of WAPs directed toward lower } \\
\text { income homes, whether government-subsidized or } \\
\text { driven by utilities and non-profit organizations } \\
\text { (current annual federal funding levels and state } \\
\text { matching would result in about 46,000 homes } \\
\text { weatherized each year). } \\
\text { - Because this can be a do-it-yourself, generally } \\
\text { affordable measure, this market segment could also } \\
\text { be reached by general informational campaigns } \\
\text { coming from any program or retailer. }\end{array}$ & $\begin{array}{l}\text { - WAPs } \\
\text { direct contact with private } \\
\text { homeowners considering home } \\
\text { performance upgrades. Outreach } \\
\text { and education (by manufacturers } \\
\text { or DOE) should be considered. }\end{array}$ \\
\hline Public housing & $\begin{array}{l}\text { - The size of this market is directly linked to HUD } \\
\text { budgets directed toward retrofits and WAPs }\end{array}$ & $\begin{array}{l}\text { - WAPs } \\
\text { - HUD budgets and programs }\end{array}$ \\
\hline $\begin{array}{l}\text { Federally } \\
\text { owned } \\
\text { residential } \\
\text { buildings }\end{array}$ & $\begin{array}{l}\text { The size of this market is linked to federal mandates } \\
\text { directed toward improving the efficiency of the } \\
\text { existing federally owned building stock as well as the } \\
\text { budgets and programs used to implement these } \\
\text { efficiency retrofits. It is also influenced by standards } \\
\text { and rating programs, as the legislative requirements } \\
\text { and Executive Orders refer to ratings }\end{array}$ & $\begin{array}{l}\text { - FEMP budgets and programs } \\
\text { - } \text { DOD budgets and programs } \\
\text { - GSA budgets and programs } \\
\text { - EPacT, EISA, and the executive } \\
\text { orders will often refer to Energy } \\
\text { Star and NFRC-rated products to } \\
\text { guide decision-making. }\end{array}$ \\
\hline $\begin{array}{l}\text { Applicable } \\
\text { commercial } \\
\text { stock }\end{array}$ & $\begin{array}{l}\text { Approximately } 2 \% \text { of commercial building stock is } \\
\text { retrofitted each year; low-e storm windows could find } \\
\text { point of entry during this natural renovation/retrofit } \\
\text { process with some level of outreach and education. }\end{array}$ & $\begin{array}{l}\text { - DOE's CBI team } \\
\text { - Overall transformation and } \\
\text { outreach efforts could influence } \\
\text { this market }\end{array}$ \\
\hline
\end{tabular}




\subsection{Lab Homes Testing and Modeling}

The lab home testing will be a continuation of FY 2013 work to evaluate the energy-savings potential of installing low-e storm windows over typical double-pane aluminum windows in PNNL's matched pair of Lab Homes. The performance of the one home's HVAC system (the thermal performance of the home) will be measured and compared to the thermal performance of the other home without low-e storm windows during heating and cooling season periods. Both homes will deploy identical simulated occupancy schedules so that the performance and effects of the low-e storm windows will be isolated from all other variables. The details of this task plan are provided in a 2013 Experimental Plan (Widder 2013).

The results from this proposed project will be captured in a technical report and made available to regional and national stakeholders who have an interest in low-e storm windows as an energy-efficiency measure. The results will also be used to inform a concurrent effort to develop a rating system for low-e storm windows, which PNNL is also supporting. This will form the basis of many of the outreach and technical assistance efforts, confirming and validating energy performance of low-e panels.

\subsection{Technical Assistance}

Building America will continue its role as an honest broker of research and information related to low-e storm window performance by determining and validating the performance of low-e storm windows, including how different circumstances and climate regions may affect this performance, and tailoring modeling tools to integrate low-e storm window performance. Technical assistance should be provided on a somewhat "as-needed" basis to core customers, including utilities and weatherization programs, rating developers, and those providing building simulation modeling and retrofit design support to the private homes and the federal sector. Technical support would include assisting core customers to validate low-e storm window performance in multiple climate zones and assisting core customers to tailor analysis and tools to WAP/utility criteria to integrate low-e storm windows and weatherization measures.

Technical assistance may also be provided in support of outreach efforts to help disseminate information to relevant stakeholders, leveraging credibility from Building America, DOE, and national laboratories. Efforts should be made to continue participating in and assisting CEE working groups to develop window attachment standards and develop outreach material. In addition to this technical assistance provided on an as-needed basis, technical assistance should purposefully coordinate with the low-e storm window-related activities in the CSI team and with DOE developers of pending window attachment ratings and Home Energy Score.

\subsubsection{Codes and Standards Innovation Team}

As market transformation to third-party installations increases, there may be code barriers that need to be addressed for low-e storm windows. The Building America CSI team is currently conducting a pilot study of processes using storm windows as an example measure to be examined as part of the pilot. Technical assistance will be provided to review material throughout the pilot and evaluate whether or not attributes of storm windows are adequately captured in the CSI-proposed process. 


\subsubsection{Rating System Support}

Technical assistance could be provided to conduct analysis to assess low-e storm window integration into other residential building energy models and ratings systems commonly used to facilitate energyefficiency retrofits (e.g., EnergyGauge, BeOpt, Home Energy Rating System, and Home Energy Score). Conduct analysis to assess low-e storm window integration into other residential building energy models and ratings systems commonly used to facilitate energy-efficiency retrofits (e.g., EnergyGauge, BeOpt, Home Energy Rating System score, and Home Energy Score). This will also involve monitoring and participating as needed in activities related to DOE's effort to create a program to rate and certify the performance of fenestration attachments. ${ }^{9}$ Home Energy Score currently does not account for the impact of storm windows and technical assistance may be requested to develop appropriate parameters to model this measure.

\subsection{Outreach}

Outreach will be conducted with the following core customers: Building America teams, state and regional utilities and utility groups, state and federal WAPs, rating and labeling organizations, federal agencies that either sponsor residential building-related programs (e.g., EPA, FEMP) or are custodians of residential building stock (e.g., DOD, GSA, HUD).

Building America Teams. Identify teams working in regions where low-e storm windows have the highest SIR and are working with retrofits and examine whether low-e storm windows can be integrated into project proposals and strategies.

Weatherization outreach. The size of this market is largely influenced by the size and structure of WAPs directed toward lower income homes, whether government-subsidized or driven by utilities and non-profit organizations (current annual federal funding levels and state matching funds would result in about 46,000 homes being weatherized each year). Some leads have been established and the following activities should be pursued:

- Follow leads with the state weatherization programs and initiate contacts with states in climate zones where low-e storm windows have high SIRs. Provide summary material on weatherization benefits of low-e storm window applications. Examine whether low-e storm windows could be integrated on priority and qualified lists of weatherization measures in current or future cycles.

- Reach out to Tribal Nations as related to their weatherization efforts should be included.

- Attend annual weatherization conference ${ }^{10}$.

- Contact HUD representatives and offer weatherization material related to low-e storm windows.

Utility outreach. This market could grow if more direct utility incentive programs were put into place and programs such as Energy Star were to include low-e storm windows. (On average about 1-2\%

\footnotetext{
${ }^{9}$ See DE-FOA-0001015: Notice of Intent: Certification and Rating of Attachments for Fenestration Technologies (DRAFT), for more information.

${ }^{10}$ The WAP program is currently restructuring the program and the format of some of annual conferences that have been held in the past; thus, the exact conference or workshop targeted for this effort has not yet been determined.
} 
of homes perform energy-related retrofits each year.) To reach this sector, the following activities should be pursued:

- Continue interactions and participation in CEE working groups and outreach efforts and attend the CEE conference in September 2014.

- Find all utility regions/states where storm windows are currently included as incentive measures and provide information about low-e storm windows.

- Follow initial contacts made with the Bonneville Power Administration and other utility groups to determine what educational and outreach tools would most effectively reach the utility audiences. Initiate contact with utilities where RESFEN results in the highest returns and learn more about incentives.

- Work with the Northwest Power Planning Council to examine the possibility of integrating low-e storm windows into the 7th Power Plan. ${ }^{11}$

- Propose to participate in utility-sponsored energy-efficiency workshops in the Northeast, Midwest, and Northwest (e.g., Northwest Energy Efficiency Exchange in May).

Energy Star outreach. This market could grow if programs targeting residential retrofits, such as HPwES and BB included directed education/training and outreach efforts toward low-e storm windows (HPwES retrofit 50,000 homes in 2011). Activities related to this effort should include the following:

- Work with HPwES and Energy Star windows administrators on issues related to low-e storms (e.g., integrating into Home Performance measures and the rating of Energy Star products) over time.

- Monitor and participate as needed in activities related to DOE's effort to create a program to rate and certify the performance of fenestration attachments.

FEMP/DOD/GSA outreach. The size of this market is linked to federal mandates directed toward improving the efficiency of existing federally owned building stock as well as the budgets and programs used to implement these efficiency retrofits. It is also influenced by standards and rating programs, as the legislative requirements and Executive Orders refer to ratings. Strategies to reach this group will include the following:

- Initiate integration of low-e storm windows into the Federal Energy Decision System model (the underlying model for DOD and other federal facility building energy retrofits).

- Initiate contact with GSA, FEMP, and DOD representatives charged with managing the federal sector effort to meet aggressive building energy savings goals.

\footnotetext{
${ }^{11}$ The Council develops a plan, updated every five years, focused on informing the region's power supply planning and to ensure that it acquires cost-effective energy efficiency measures as part of this plan.
} 


\subsection{References}

AAMA (American Architectural Manufacturers Association). 2012. "Window and Door Sales to Accelerate Next Year.” Window \& Door Magazine. Volume 20, Number 4, June/July 2012,

American Recovery and Reinvestment Act (ARRA) of 2009. Public Law 111-5; 123 Stat. 115.

ASHRAE (formerly American Society for Heating, Refrigerating and Air-Conditioning Engineers). 2013. Energy Standard for Buildings Except Low-Rise Residential Buildings, Standard 90.1-2013, Atlanta, Georgia.

Cort KA. 2013. Low-e Storm Windows: Market Assessment and Pathways to Market Transformation PNNL-22565, Pacific Northwest National Laboratory, Richland, Washington.

Culp TD, and KA Cort. 2013. Database of Low-E Storm Window Energy Performance across U.S. Climate Zones (Task ET-WIN-PNNL-FY13-01_5.3). PNNL-22864, Pacific Northwest National Laboratory, Richland, Washington.

DOE (U.S. Department of Energy). 2011. "Buildings Energy Data Book.” U.S. Department of Energy Office of Energy Efficiency and Renewable Energy, Washington, D.C. Available at http://buildingsdatabook.eren.doe.gov/DataBooks.aspx.

DOE-EIA(U.S. Department of Energy-Energy Information Administration). 2005. 2005 Residential Energy Consumption Survey: Housing Characteristics. Washington, D.C.

DOE-EIA(U.S. Department of Energy-Energy Information Administration). 2009. 2009 Residential Energy Consumption Survey: Housing Characteristics. Washington, D.C.

Drumheller, SC, C Kohler, and S Minen. 2007. Field Evaluation of Low-e Storm Windows. LBNL-1940E, Lawrence Berkley National Laboratory, Berkeley, California.

Energy Independence and Security Act (EISA) of 2007. Public Law 110-140.

Energy Policy Act (EPAct) of 2005. Public Law 109-58.

Hefty MG and TL Gilbride. 2013. Low-E Storm Windows \& Panels: A New Tool for Utility and Weatherization Programs. PNNL-SA-95392, Pacific Northwest National Laboratory, Richland, Washington.

Hefty MG, TD Culp, and SH Widder. 2013. Task Plan in Support of Emerging Technology Task ET-WIN-PNNL-FY13-01_5.1: Create a Database of U.S. Climate-Based Analysis for Low-E Storm Windows. PNNL-22307, Pacific Northwest National Laboratory, Richland, Washington.

JCHS(Joint Center for Housing Studies). 2013. The U.S. Housing Stock Ready for Renewal: Improving America’s Housing 2013. Harvard University, Cambridge, Massachusetts. 
Nadel S and H Geller. 1996. "Market transformation programs: Past results and new initiatives.” American Council for an Energy-Efficient Economy, Washington, D.C.

PNNL(Pacific Northwest National Laboratory). 2012. A Business Case for Home Performance Contracting. PNNL-21196, prepared by MC Baechler, CA Antonopoulos, M Sevigny, TL Gilbride, and MG Hefty, Pacific Northwest National Laboratory, Richland, Washington.

Quanta Technologies. 2013. “2012-13 Quarterly Reports.” Prepared for U.S. Department of Energy under DOE EERE award \#DE-EE0004015, Malvern, PA.

USBC (U.S. Bureau of Census). 2012. American Housing Survey 2012. Table C-10-AO. Survey information available online at http://www.census.gov/programs-surveys/ahs/.

Widder S. 2013. "Demonstration of Low-e Storm Windows in PNNL Lab Home: Experimental Plan Draft 3.” April 3, 2013. Pacific Northwest National Laboratory, Richland, Washington.

Zalis W, T Culp, C Kohler, and PM LaFrance. 2010. Evaluation of Low-E Storm and R-5 Windows for Inclusion in Pennsylvania's Weatherization Priority List. Energetics, Columbia, Maryland, Birch Point Consulting, La Crosse, Wisconsin; Lawrence Berkeley National Laboratory, Berkeley, California; and U.S. Department of Energy. Prepared for the Pennsylvania Department of Community and Economic Development, Harrisburg, Pennsylvania. 



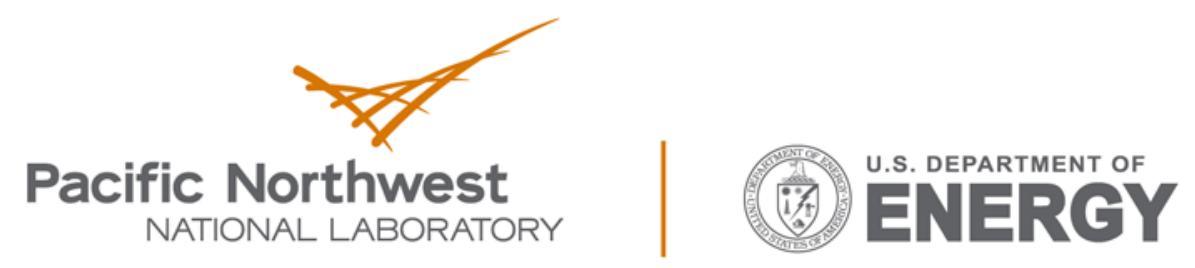

Proudly Operated by Battelle Since 1965

902 Battelle Boulevard

P.O. Box 999

Richland, WA 99352

1-888-375-PNNL (7665)

www.pnnl.gov 